140 BOOK REVIEWS

All three institutions shared habitual Jesuit characteristics: a belief that moral reform was achievable through the exercise of the individual's will, and a commitment to reaching those on the margins of society by recruiting the support of urban elites. These institutions (founded in the 1540s) were unusual, however, in the amount of initiative they granted to their lay overseers: a result, Lazar explains, of the itinerant nature of the early Jesuit ministry. Lazar offers detailed analyses of life inside these places and the patronage networks that supported them. This book adds considerable weight to the notion that charity in this period took on a more redemptive mission rather than primarily being an exercise in social control.

JONATHAN WRIGHT, Hartlepool, United Kingdom

\title{
Michelle O'Malley \\ The Business of Art: Contracts and the Commissioning Process in Renaissance Italy
}

New Haven and London: Yale University Press, 2005. Pp. x, 358.

It was Michael Baxandall who said that economic agreements between painters and patrons were situated within the social nexus, thus paving the way for such books as O'Malley's. This volume is a welcome addition to studies of the "material Renaissance": it not only gives us insights into the economic context, but also offers hugely valuable readings of such ideas as contract, value, and subject matter, all of which, as it shows, informed the commissioning process. Organised into three main sections, "Materials and Production," "Estimation of Worth," and "Pictorial Matters," this book surveys economic trends using methods familiar to and remote from art historical approaches, so that iconographic analysis sits alongside statistical evaluation of prices, artistic materials, and demographic factors, all presented in tables. Using raw economic data such as the price paid for gold leaf and other materials in altarpieces from the 1350 s to the mid 1520s, O'Malley tentatively constructs an economic model that allows us to gain insight into this culture of negotiation. If there is a weakness in this study of economic lives of painters, it is that the evidence is incomplete, having been lost to the accidents of history. O'Malley is aware of this, and of course such a project as this can always be updated if fresh facts about paintings, prices, and contracts come to light. An extremely valuable and welcome study that brings the economic life of Renaissance Italy into sharp focus.

DAVID PACKWOOD, University of Warwick 